\title{
Usefulness of Objective Hearing Tests for Screening Patients with Partial Deafness
}

\author{
Min Ji Yu, Hyung-Ah Mun, Jong Joo Lee, Young Sook Kang, \\ Soo Ah Hong, Hye Jin Lim, Hun Yi Park, and Yun-Hoon Choung \\ Department of Otolaryngology, Ajou University School of Medicine, Suwon, Korea
}

\author{
부분적 전농 환자 선별을 위한 객관적 청각검사의 유용성 \\ 유민지 · 문형아 - 이종주 · 강영숙 · 홍수아 · 임혜진 · 박헌이 · 정연훈 \\ 아주대학교 의과대학 이비인후과학교실
}

Received November 5, 2014

Revised February 4, 2015

Accepted February 14, 2015

Address for correspondence

Yun-Hoon Choung, DDS, MD, PhD

Department of Otolaryngology,

Ajou University School of Medicine,

164 World cup-ro, Yeongtong-gu,

Suwon 443-380, Korea

Tel $+82-31-219-5263$

Fax $+82-31-219-5264$

E-mail yhc@ajou.ac.kr
Background and Objectives 'Partial deafness', characterized by normal or slightly impaired hearing in the low frequency band and nearly total deafness in the high frequency range, is difficult to assess with conventional behavioral tests in infants and young children. Therefore, this study aimed to assess the usefulness of objective hearing tests, such as auditory brainstem response (ABR) and auditory steady state response (ASSR) in evaluating patients with partial deafness.

Subjects and Method One hundred thirty three patients who underwent ASSR in Ajou University Hospital from January 2008 to January 2013 were enrolled to this study. Correlations between ASSR, ABR and pure tone audiometry (PTA) thresholds were analyzed.

Results ASSR thresholds of 133 patients were highly correlated with both ABR and PTA thresholds in majority of the tested frequencies. Partial deafness was detected in 9 out of 133 patients, based on the results of PTA and ASSR. ASSR thresholds of patients with partial deafness were significantly correlated with PTA thresholds in all frequencies, with especially high correlation found at 1 and $4 \mathrm{kHz}$. However, there was no significant correlation between ASSR and ABR thresholds. ABR thresholds of partial deafness patients were measured at $65 \mathrm{~dB}$ in one patient, $70-90 \mathrm{~dB}$ in 3 patients, and no response at $90 \mathrm{~dB}$ in 5 patients, respectively. In 8 $(6 \%)$ out of 124 patients, ABR thresholds were measurable with profound hearing loss and residual hearing was observed at low frequencies.

Conclusion ASSR is useful for predicting residual hearing at low frequencies of infants and young children for whom assessment of hearing is difficult using conventional behavioral tests. Korean J Otorhinolaryngol-Head Neck Surg 2015;58(8):540-6

Key Words Auditory brainstem response $\cdot$ Auditory steady-state response $\cdot$ Deafness.

\section{서 론}

저주파수의 청력이 정상 혹은 경도 난청을 보이지만 고주 파수의 청력이 고심도 난청에 가깝게 손상된 청력손실을 부 분적 전농(partial deafness)이라 한다. ${ }^{1,2)}$ 이러한 청력을 보이 는 환자들은 일상생활이나 음악감상 등 다양한 소리를 듣지 못하고, 특히 소음 상황에서 어음 이해도가 떨어지기 때문에
삶의 질이 떨어진다. ${ }^{3)}$ 또한 보청기로 재활을 할 경우에는 저주 파수의 되울림 효과 때문에 고주파수음 증폭에 제한이 생겨 환자의 만족도가 낮고 인공와우로 재활을 할 경우에는 저주 파수의 소리가 자연스럽게 들리는 것에 비해 인공와우를 통 한 전기적 자극이 부자연스러워 전체적인 음의 질이 나빠져 환 자들이 적응하는 데 어려움이 존재한다.

전기적 자극만을 통한 인공와우 사용자들의 어음처리과정 
은 소음 속 어음인지나 음악을 즐기는 데 있어 시간적 정보처 리에 한계가 있어 부정적인 결과를 보여주었다. ${ }^{3)}$ 특히 음악과 관련하여 인공와우 환자들은 정상 청력인보다 음의 높낮이 의 변화를 탐지하고 변별하는 능력에서 수행력이 떨어지고 있었다. ${ }^{4)}$ 최근 정원창 삽입술을 통한 잔존청력 보존 수술이 확대됨에 따라, 전기적 자극과 음향학적 자극을 같은 귀에 동시에 전달해 주는 electric acoustic stimulation(EAS)을 통 해 부분적 전농 대상자들에게 적합한 재활을 할 수 있게 되 었다. 보청기와 인공와우를 같은 귀에 자극했을 때 하나의 보장구를 사용했을 때보다 듣기와 말 인지 능력이 더 좋다고 보고되었다. ${ }^{5)} \mathrm{EAS}$ 는 저주파수 잔존청력이 있는 환자들에게 있어 이론적으로 설명될 뿐 아니라 임상적으로도 잔존청력 을 보존함으로써 이득이 입증되었다. 잔존청력 보존술을 통 한 저주파수의 음향학적 자극은 시간적 처리에 있어 질 좋 은 정보를 제공하여 음악의 질뿐만 아니라 소음 속 청취에도 이득을 주는 것을 확인할 수 있었다. ${ }^{3)}$

부분적 전농 아동을 대상으로 한 연구에서 어음인지, 음성, 음율 평가를 시행한 결과 인공와우나 보청기를 통한 재활보 다는 EAS에서 더 높은 점수를 보였고, ${ }^{5)}$ 부분적 전농 아동의 재활 시 보청기를 사용하는 것보다 EAS를 사용하는 것이 어 음인지나 소음상황에서 더 효과적이라고 하였다.)

성인 환자들은 순음청력검사(pure tone audiometry, PTA) 로 부분적 전농을 쉽게 파악할 수 있지만, 협조가 잘 되지 않 은 영·유아 환자들은 주관적 검사로 난청의 형태나 정도를 정확히 파악하는 것은 어렵다. 객관적 청력검사로 주로 사용 되는 청성뇌간반응(auditory brainstem response, ABR)은 청신경에서 뇌간에 이르는 청각 전달로에서 발생하는 전위 를 기록함으로써 청력을 예측할 수 있다. 주로 넓은 주파수 대역을 갖고 와우 전체를 자극할 수 있는 클릭음을 사용하지 만, 주파수 특이성이 낮고 특히 저주파수 정보 제공에 제한 적이기 때문에 $\mathrm{ABR}$ 만으로는 저주파수 잔존청력의 정확한 평 가가 어렵다. 이를 보완하기 위한 검사로 청성지속반응검사 (auditory steady state response, ASSR)는 진폭이나 주파 수를 주기적으로 변조한 순음에 대한 청각전달로의 지속적 인 반응이다.) 변조된 순음을 사용하기 때문에 클릭음보다 와우의 좁은 부위를 자극하게 되어 주파수 특이성이 더 넓 고." 클릭음이나 tone burst 자극 시 발생하는 자극음의 왜곡 현상이 적게 발생하고 높은 진폭의 자극음으로 측정할 수 있 다. ${ }^{8)}$ 영·유아의 난청 형태나 정도 파악을 위해서는 객관적 검 사들의 장단점을 파악하고 이를 상호 보완적으로 적용해서 청력을 예측해야 한다.

본 연구는 주파수별 역치 차가 큰 부분적 전농 환자의 청력 을 객관적 검사를 통해 예측하고 주파수별 상관관계를 파악
하여 부분적 전농의 효과적 선별을 위한 객관적 검사의 유용 성을 확인하는 데 그 목적이 있다.

\section{대상 및 방법}

\section{대 상}

2008년 1월부터 2013년 1월까지 난청을 주소로 내원한 환자 중 ASSR을 1 회 이상 시행한 환자 133명을 대상으로 하여 후향 분석하였다. 남자 71명, 여자 62명이었다. 평균 연령은 $16.2( \pm$ 22.8)세로 연령범위는 3 개월에서 88세였다. 모든 대상자는 $\mathrm{ASSR}$ 을 시행하였고 $\mathrm{ABR}$ 을 함께 시행한 군은 124 명, $\mathrm{PTA}$ 를 함께 시행한 군은 54명, $\mathrm{ABR}$ 과 $\mathrm{PTA}$ 를 모두 시행한 군은 45 명이었다. 부분적 전농 그룹의 환자들은 EAS의 대상자가 되 므로 ${ }^{3)} \mathrm{EAS}$ 대상자 선정을 위한 청력도(Fig. 1)를 참고하여 ASSR과 PTA의 주파수별 역치를 통해 $500 \mathrm{~Hz}$ 이하의 청력 역치가 $65 \mathrm{~dB}$ 이하인 청력도만을 선별하였다.

\section{연구장비 및 연구방법}

ASSR은 MASTER II(Bio-logic System, Mundelein, IL, USA)를 사용하였고, carrier frequency는 500, 1000, 2000, $4000 \mathrm{~Hz}$ 이고 modulation frequency는 82 99 Hz였다. 출력 간격은 $10 \mathrm{~dB}$, 출력 범위는 10 110 dB까지 가능하였고, $90 \mathrm{~dB}$ 이상의 자극에서는 한 개의 주파수씩 역치를 측정하였다. 활 성전극(active electrode)은 두정부에 위치하였고, 기준전극 (reference electrode)은 양측 유양 돌기에, 접지전극(ground electrode)은 앞이마에 부착하여 1-channel 전극을 사용하 였다.

ABR은 Navigator pro EP(Bio-logic System, Mundelein, $\mathrm{IL}, \mathrm{USA}$ )를 사용하였고 자극음은 클릭음을 사용하였다. 출 력 간격은 $5 \mathrm{~dB}$ 씩 조절하였고, 출력 범위는 10 90 dB까지 가 능하였다. 활성전극(active electrode)은 두정부에 위치하였 고 기준전극(reference electrode)은 양측 유양 돌기, 접지전 극(ground electrode)은 앞이마에 부착하여 2-channel 전극 을 사용하였다. 두 검사의 저항 값은 모두 $5 \mathrm{k} \Omega$ 이하로 조정 하였다.

PTA는 Orbiter 922(Madsen, Taastrup, Denmark)와 Aurical(GN otometrics, Taastrup, Denmark)을 사용하였다. 출 력 간격은 $10 \mathrm{~dB}$ 씩 상승, $5 \mathrm{~dB}$ 씩 하강하는 수정 상승법으로 측정하였고, 출력 범위는 -5 에서 $110 \mathrm{~dB}$ 까지 측정하였다. 유 소아 청력검사는 6 개월 미만인 경우 행동관찰청력검사, 6 24개월의 경우 시각강화청력검사, 2 5세의 경우 유희청력 검사 등을 실시하였다. $\mathrm{ASSR}, \mathrm{ABR}, \mathrm{PTA}$ 모두 외부 자극과 분리된 무음향방음실(Acoustic system, Austin, TX, USA)에 
서 실시하였다.

\section{분석방법}

통계분석은 윈도우용 SPSS v15.0(SPSS Inc., Chicago, IL, $\mathrm{USA}$ )을 사용하여 각 검사 간의 상관관계를 분석하였고 $p^{-}$ value $<0.05$ 를 기준으로 유효성을 판정하였다. 모든 피검자 의 역치 비교 시에는 모수적 검정(Pearson correlation)을 이용 하였고 부분적 전농으로 분류된 그룹의 통계 분석 시 표본수 가 적어 비모수 검정(Spearman correlation)을 이용하였다.

\section{결 과}

EAS의 대상자의 청력도를 참고하여(Fig. 1) ASSR과 PTA 를 통해 얻은 주파수별 역치와 청능 훈련으로 얻은 역치로 부분적 전농 환자군을 선별하였고 133명 중 9명으로 총 17귀 가 이에 해당하였다. S4의 경우 반대측 역치가 부분적 전농 에 해당하지 않아 한쪽 귀의 청력만을 입력하였다. 9 명의 연령 분포는 만 1세 6개월에서 58세로 평균 22.06( \pm 21.01$)$ 세였다. $\mathrm{ASSR}$ 과 $\mathrm{ABR}$ 을 시행한 124 명은 $\mathrm{ASSR}$ 의 주파수별 역치와 $\mathrm{ABR}$ 역치 간의 상관계수는 모든 주파수에서 0.83 이상이었 고 $1000 \mathrm{~Hz}$ 에서 가장 높았다. 부분적 전농 그룹에 해당한 9 명은 두 검사 간 주파수별 상관관계를 보이지 않았다(Fig. 2). ASSR과 PTA를 시행한 54명의 각 주파수별 역치 상관계



Fig. 1. The audiograms of 9 patients with partial deafness. The red shaded area represents the appropriate hearing loss range for EAS candidates and the solid line represents the audiograms of 9 patients with partial deafness as screened ( $n=17$ ears). EAS: electric acoustic stimulation.
수는 모든 주파수에서 0.72 이상이었고 특히 $4000 \mathrm{~Hz}$ 에서 가장 높았다. 부분적 전농 그룹에 해당한 9명 역시 ASSR과 $\mathrm{PTA}$ 의 주파수별 역치의 상관관계에서 모든 주파수 간 유의 미한 상관관계를 보였고, $1000 \mathrm{~Hz}$ 에서 가장 높은 상관계수 를 보였다(Fig. 3).

부분적 전농으로 선별된 이들의 $\mathrm{ABR}$ 역치는 각각 $65 \mathrm{~dB} 1$ 명, 70 90 dB 3명, 90 dB에서 반응이 없는 5명이었고(Fig. 4), $\mathrm{ABR}$ 역치로만 청력 정도를 판단할 경우 고심도 이상의 난청 에 8명이 해당하였다. 이들은 연령이나 재활에 대한 의지를 고 려하여 치료 보장구를 선택하였다. 모두 양측 보장구를 사용 하였으며, 보청기를 착용한 경우가 4명, 인공와우 수술을 받 고 반대측에 보청기를 착용하는 경우가 4명, EAS 수술을 받 고 반대측에 보청기를 착용하는 경우가 1명이었다(Table 1). 9 명 중 2명은 생후 6개월에 $\mathrm{ABR}$ 결과 $80 \mathrm{~dB}$ 이상으로 보청기 를 처방받아 재활을 시작하였고, 시각강화검사를 통해 보청 기 착용 전후 청력검사를 정확한 역치가 측정될 때까지 최소 6 개월 이상 진행되었고 객관적 검사 시점과의 간격은 모두 1년 이내로 가능하였다. 현재까지 모두 보청기만으로 재활 중이 다. 9명 중 유일하게 $\mathrm{EAS}$ 를 이식한 환자의 경우 7세경 $\mathrm{ABR}$ 역치가 $70 \mathrm{~dB}$ 로 측정되어 보청기를 착용하였으나 충분한 소 리자극이 되지 못해 언어발달에 진전을 보이지 않았다. 10세 경 다시 내원하여 EAS 이식하였고, EAS 착용 청력 역치가 전 주파수에서 $35 \mathrm{~dB}$ 이내로 측정되었고 수술 후 1년 언어평가 에서 수술 전보다 2년 정도의 진전을 보여주었다.

\section{고 찰}

부분적 전농과 같이 잔존청력이 있는 귀에 보청기와 인공 와우가 혼합된 $\mathrm{EAS}$ 의 사용은 이론적으로 적절할 뿐 아니라 정교한 전극을 통해 와우 내 전극 삽입 시 외상을 줄일 수 있 다. ${ }^{3)}$ 부분적 전농 환자에서 보청기를 사용했을 때보다 EAS 를 이식했을 때 단음절 검사는 $35 \%$ 에서 $67 \%$, 문장검사는 49\%에서 95\%로 향상되었고 Abbreviated Profile of Hearing Aid Benefit 설문지 결과 background noise, reverberation, aversiveness, and ease of communication 모든 항목에서 수 술 전에 비해 유의미하게 좋은 검수를 보여주었다고 보고하 였다.")

본 연구에서 선별된 부분적 전농 환자 9 명 중 인공와우 혹 은 $\mathrm{EAS}$ 를 이식받은 5명은 모두 수술 전 보청기 착용 경험이 있었으며 보장구 착용 후 보정된 청력 역치는 모든 주파수에 서 $35 \mathrm{~dB}$ 이하를 유지하고 있었다. 하지만 5명 중 한 명은 반 대쪽 잔존청력의 영향으로 인공와우를 통한 자극에 적응하 지 못하여 착용을 하지 않고 있었지만 이를 제외한 4 명은 수 

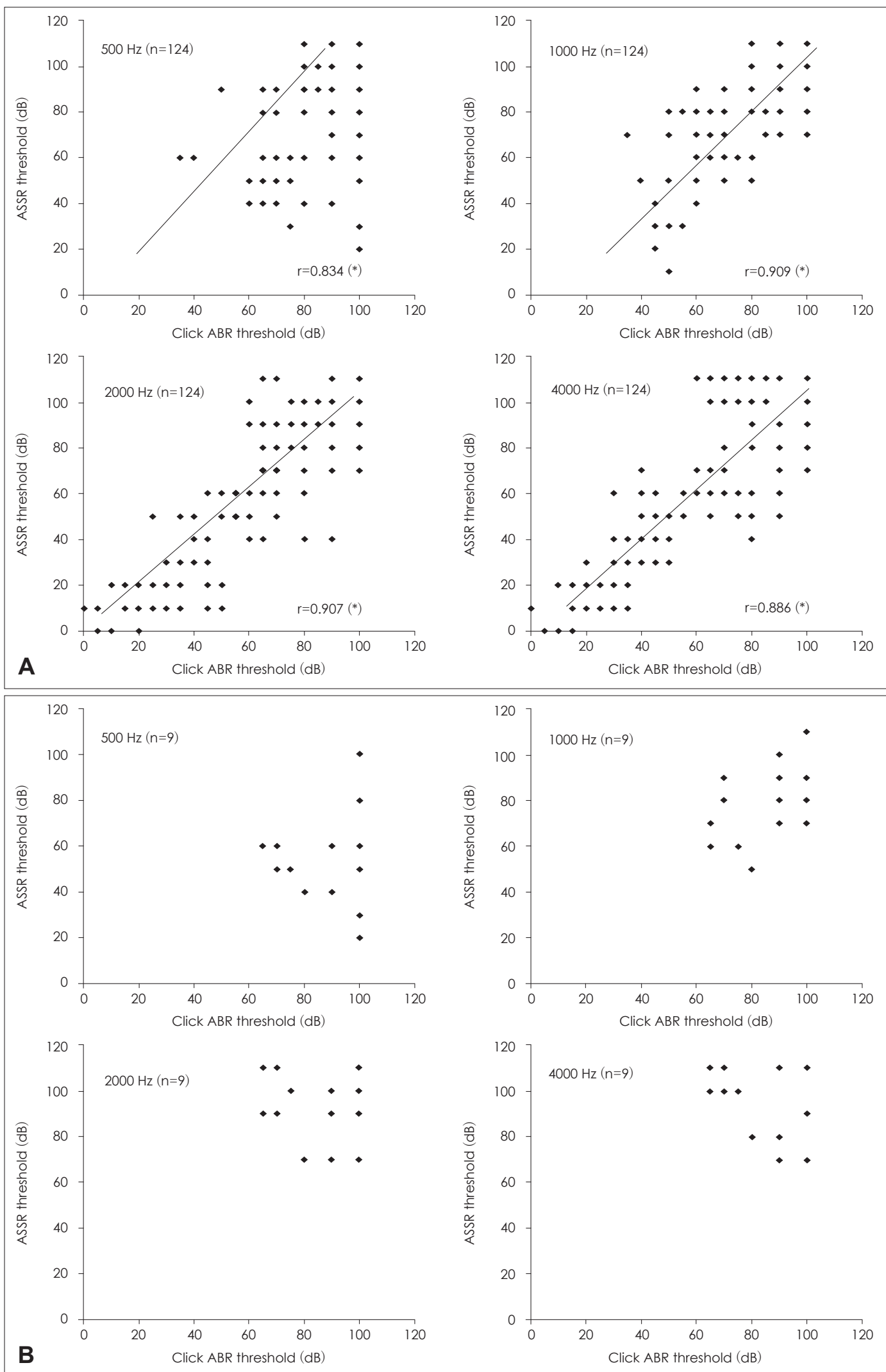

Fig. 2. Correlation between $A B R$ and $A S S R$ in each frequency. Correlation between $A B R$ and $A S S R$ thresholds for the patients as tested according to the ABR and ASSR $(n=124)\left({ }^{*} p<0.01\right)(A)$. Correlation between ABR and ASSR thresholds for the patients with partial deafness $(n=9)(p>0.05)(B)$. ABR: auditory brainstem response, ASSR: auditory steady state response. 

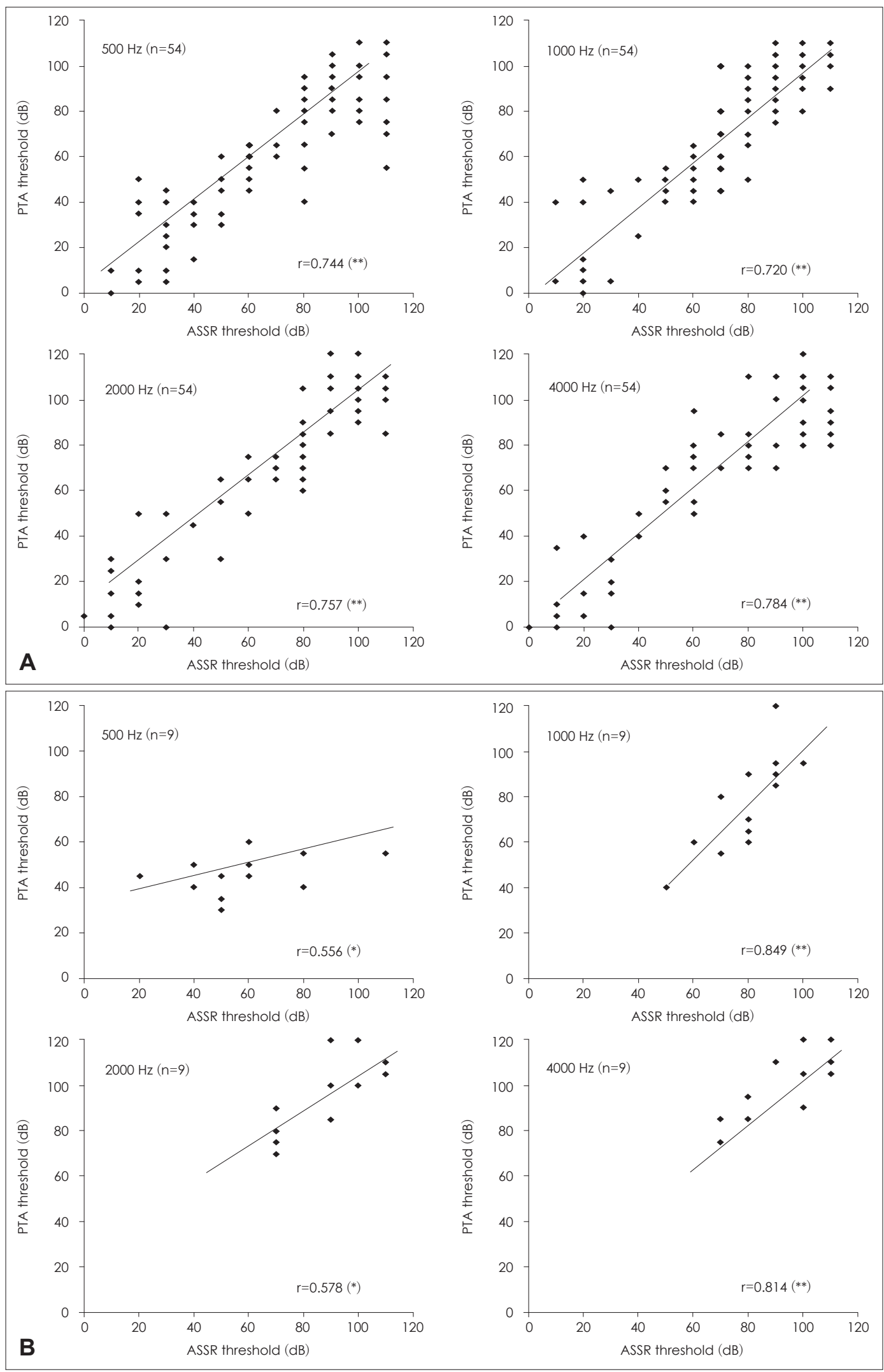

Fig. 3. Correlation between ASSR and PTA in each frequency. Correlation between ASSR and PTA thresholds for the patients as tested according to the ASSR and PTA $(n=54)\left({ }^{* *} p<0.01\right)(A)$. Correlation between ASSR and PTA thresholds for the patients with partial deafness $(\mathrm{n}=9)\left({ }^{*} p<0.05,{ }^{* *} p<0.01\right)(\mathrm{B})$. ASSR: auditory steady state response, PTA: pure tone audiometry. 
술 후 categories of auditory performance 점수가 최소 6단 계(입 모양을 보지 않고 친숙한 사람과 대화하는 단계) 이상, 1 음절 단어점수는 최소 $68 \%$, 최대 $96 \%$ 의 수행력을 보였다.

부분적 전농 환자의 선별은 주관적 청력검사가 가능하다 면 어렵지 않지만 행동학적 청력검사가 어려운 유소아의 경 우 주파수별 역치 차가 많이 나는 부분적 전농을 객관적 검 사만을 통해 선별해야 하므로 어려움이 있다. 객관적 청력검 사인 $\mathrm{ABR}$ 과 $\mathrm{ASSR}$ 은 역치를 예측하는 것이지 그 역치를 정확 하게 의미하는 것은 아니다. 또 청성 자극을 주고 청성 기관

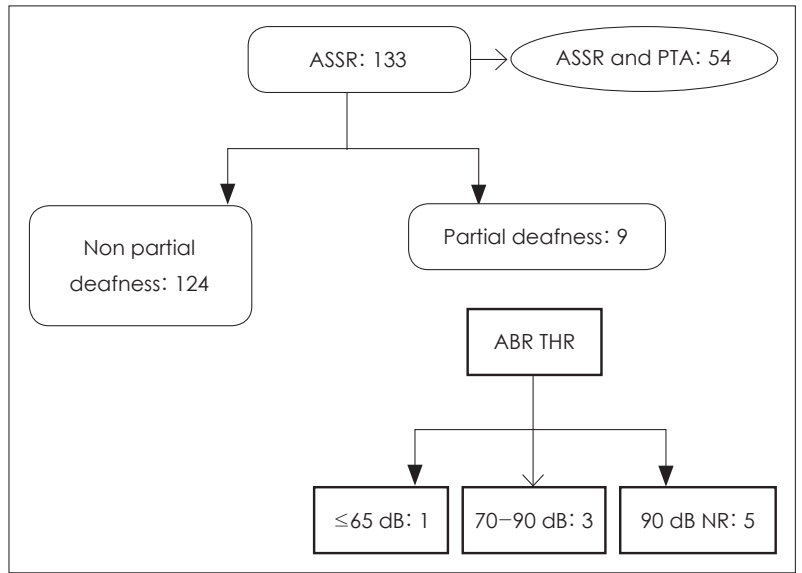

Fig. 4. ABR thresholds of 9 patients with partial deafness. THR threshold, NR: no response, ABR: auditory brainstem response, ASSR: auditory steady state response, PTA: pure tone audiometry.
에서 생성되는 신경전위라고 알려진 발현시간에 나타나는 전 위가 주변 소음(뇌 표면, 근육 등에서 발현되는 무작위의 전 위)과 분명히 구분되어지는 전위로 역치를 측정하므로 순음 청력검사의 역치와 유발전위를 이용하여 측정한 역치에서 차 이가 나는 것은 당연하다. ${ }^{10,11)} \mathrm{ABR}$ 과 $\mathrm{ASSR}$ 이 실제 청력 역 치와 상관관계가 높다고 알려져 있지만, 영·유아의 청력검사 로 가장 많이 이용되는 click음을 사용한 ABR은 $2 \sim 4 \mathrm{kHz}$ 대 역의 청력 역치를 반영했기 때문에 저주파수 역치 측정에 한 계가 있고, ${ }^{12,13)} \mathrm{ASSR}$ 역시 고음역의 청력저하가 있는 청력도 에서는 PTA의 청력도를 잘 반영하나 청력이 정상에 가까울 수록 PTA와의 상관관계가 약해진다. ${ }^{13,14)}$ 본 연구의 부분적 전 농 환자에서 신생아청력선별검사를 시행한 4 명 중 2 명(50\%)의 아동이 pass와 refer 결과가 번갈아가며 나타났다. 이는 정상 에 가까운 저주파수 잔존청력이 객관적 검사 시 측정되는 신경 전위에 영향을 미쳤을 것이라 생각된다.

객관적인 청력 역치 측정에서 click음과 tone burst음을 이 용한 $\mathrm{ABR}$ 을 먼저 시행하여 청력 역치를 구하고, 주파수별 청 력 역치의 재확인이나 심도 난청 환자의 잔존청력평가 등 추 가적인 정보가 필요한 경우 $\mathrm{ASSR}$ 을 시행하는 것이 오류 없이 영·유아의 청력 역치를 예측할 수 있는 방안이라고 권하고 있었다. ${ }^{15)}$ 난청 정도에 따라 정상청력부터 고심도 난청의 아동 을 대상으로 click을 사용한 ABR과 ASSR 간의 역치 비교에 서는 $2 \mathrm{kHz}$ 에서 높은 상관성을 보여주었지만, ${ }^{16)}$ 본 연구에서

Table 1. Demographic data for 9 patients with partial deafness

\begin{tabular}{|c|c|c|c|c|c|c|c|c|c|c|c|c|c|}
\hline & Age of & $\triangle B P$ & & & & & & & & & SPT (SDT) & Pohabilitation & Porformanco \\
\hline & diagnosis/sex & TDE & 500 & $1 \mathrm{~K}$ & $2 \mathrm{~K}$ & $4 \mathrm{~K}$ & 500 & $1 \mathrm{~K}$ & $2 \mathrm{~K}$ & $4 \mathrm{~K}$ &  & 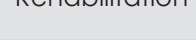 & 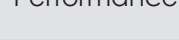 \\
\hline S1 & 1 y $6 \mathrm{~m} / \mathrm{F}$ & 90 & 40 & 80 & 70 & 70 & 40 & 65 & 80 & 75 & - & $\mathrm{HA}$ & Normal \\
\hline & 1 y $6 \mathrm{~m} / \mathrm{F}$ & NR & 20 & 80 & 70 & 70 & 45 & 70 & 90 & 85 & - & $\mathrm{HA}$ & Normal \\
\hline S2 & 1 y $8 \mathrm{~m} / \mathrm{M}$ & 80 & 40 & 50 & 70 & 80 & 40 & 40 & 70 & 85 & - & $\mathrm{HA}$ & Normal \\
\hline & 1 y $8 \mathrm{~m} / \mathrm{M}$ & 90 & 40 & 70 & 70 & 80 & 50 & 55 & 75 & 95 & - & $\mathrm{HA}$ & Normal \\
\hline S3 & 5 y $6 \mathrm{~m} / \mathrm{F}$ & 65 & 60 & 70 & 110 & 110 & 60 & 80 & 110 & 120 & - & $\mathrm{Cl}$ & Good \\
\hline & 5 y $6 \mathrm{~m} / \mathrm{F}$ & 65 & 60 & 60 & 90 & 100 & 50 & 60 & 85 & 90 & 60 & $\mathrm{HA}$ & Good \\
\hline S4 & 5 y $11 \mathrm{~m} / \mathrm{M}$ & NR & 110 & 100 & 100 & 110 & 55 & 95 & 100 & 110 & (65) & $\mathrm{HA}$ & Normal \\
\hline S5 & $11 \mathrm{y} / \mathrm{F}$ & 70 & 60 & 90 & 110 & 110 & 50 & 90 & 105 & 120 & 75 & EAS & Good \\
\hline & $11 \mathrm{y} / \mathrm{F}$ & 70 & 50 & 80 & 90 & 100 & 35 & 90 & 120 & 120 & 70 & $\mathrm{HA}$ & Good \\
\hline S6 & $26 \mathrm{y} / \mathrm{M}$ & 75 & 50 & 60 & 100 & 100 & 45 & 60 & 100 & 105 & 70 & $\mathrm{HA}$ & Poor \\
\hline & $26 \mathrm{y} / \mathrm{M}$ & NR & 60 & 80 & 100 & 110 & 55 & 70 & 110 & 120 & 80 & $\mathrm{HA}$ & Poor \\
\hline S7 & $38 \mathrm{y} / \mathrm{F}$ & NR & 80 & 90 & 90 & 90 & 55 & 95 & 100 & 110 & (40) & $\mathrm{Cl}$ & Good \\
\hline & $38 \mathrm{y} / \mathrm{F}$ & NR & 80 & 90 & 90 & 110 & 40 & 120 & 120 & 120 & (60) & $\mathrm{HA}$ & Good \\
\hline S8 & $45 \mathrm{y} / \mathrm{M}$ & NR & 50 & 90 & 100 & 110 & 30 & 85 & 120 & 120 & 50 & $\mathrm{Cl}$ & Poor \\
\hline & $45 \mathrm{y} / \mathrm{M}$ & NR & 30 & 70 & 110 & 110 & 25 & 55 & 120 & 120 & 50 & $\mathrm{HA}$ & Normal \\
\hline S9 & $58 \mathrm{y} / \mathrm{F}$ & 90 & 60 & 100 & 100 & 110 & 65 & 105 & 120 & 120 & (65) & $\mathrm{Cl}$ & Good \\
\hline & $58 \mathrm{y} / \mathrm{F}$ & 90 & 60 & 90 & 90 & 110 & 60 & 95 & 120 & 120 & (65) & $\mathrm{HA}$ & Good \\
\hline
\end{tabular}

good: amplifier wearing and over monosyllable score $50 \%$ at 1 year post-op language evaluation, normal: amplifier wearing but follow up loss, poor: refuse to wear the amplifier. ABR: auditory brainstem response, ASSR: auditory steady-state response, PTA: pure tone audiometry, SRT (SDT): speech recognition (detection) threshold, HA: hearing aid, Cl: cochlear implant, EAS: electric acoustic stimulation 
부분적 전농 환자의 $\mathrm{ABR}$ 과 $\mathrm{ASSR}$ 역치를 비교한 결과 두 검 사 간 유의미한 상관관계를 보이지 않았고 저주파수 잔존청력 의 유무를 $\mathrm{ABR}$ 검사만으로는 예측하기 어려웠다. 최근 $\mathrm{EAS}$ 환자에서 특정 유전자(mito 1555A > G, CDH23, TMPRSS3, $\mathrm{ACTG1)}$ 를 발견하였고, $\mathrm{EAS}$ 의 대상자가 되는 부분적 전농 환자들을 ASSR과 gene test를 이용하여 선별할 수 있음을 보고하였다. ${ }^{17)}$ 본 연구에서 부분적 전농 영·유아를 대상으로 시각강화 훈련 후 측정된 주관적 청력 역치가 ASSR 역치와 모든 주파수에서 의미 있는 상관관계를 보여주었다. 저주파수 잔존청력이 정상에 가깝거나 EAS 대상에 해당된다면 $\mathrm{ASSR}$ 이 저주파수 정보제공에 있어 신뢰도가 낮다고 해도 주관적 청력검사가 어려운 영·유아에서 의미 있는 청력 역치를 예측 할 수 있다.

본 연구에서 선별된 부분적 전농 환자 9 명 중 5 명은 객관적 검사를 통해 언어습득 이전 난청이 발견되었으나 소리에 반 응을 보여 재활을 미루거나 보청기 착용을 간헐적으로 착용 하고 있었고, $\mathrm{ABR}$ 결과 인공와우 급여 기준에 도달하지 못하 여 수술 연령이 늦춰져 보청기만으로 재활을 하고 있었다. 부 분적 전농 아동의 경우 객관적 검사만으로는 잔존청력의 예 측이 어렵기 때문에 부모나 비전문가의 시각에서는 아동의 단 순한 소리반응으로 청력을 의심하고 재활을 소홀히 하는 경우 가 발생할 수 있다. 따라서 행동반응청력검사가 어려운 영·유 아에서 주파수별 역치 차가 큰 부분적 전농을 선별할 때에는 객관적 검사의 장단점을 잘 파악하여 청력예측을 하는 것이 중요하다.

\section{Acknowledgments}

This work was supported by the Core Medical Instrument Commercialization Development Program (10049721, Commercialization of Customized Wireless Hearing Aids according to the Severity and Types of Hearing Impairment) funded by the Ministry of Trade, Industry and Energy (MOTIE) of Korea.

\section{REFERENCES}

1) Skarzyński H, Lorens A, Piotrowska A. A new method of partial deafness treatment. Med Sci Monit 2003;9(4):CS20-4.

2) Podskarbi-Fayette R, Pilka A, Skarzynski H. Electric stimulation complements functional residual hearing in partial deafness. Acta
Otolaryngol 2010;130(8):888-96.

3) Gantz BJ, Turner C, Gfeller KE, Lowder MW. Preservation of hearing in cochlear implant surgery: advantages of combined electrical and acoustical speech processing. Laryngoscope 2005;115(5):796-802.

4) Gfeller K, Turner C, Mehr M, Woodworth G, Fearn R, Knutson JF, et al. Recognition of familiar melodies by adult cochlear implant recipients and normal-hearing adults. Cochlear Implants Int 2002; 3(1):29-53.

5) Dorman MF, Gifford RH, Spahr AJ, McKarns SA. The benefits of combining acoustic and electric stimulation for the recognition of speech, voice and melodies. Audiol Neurootol 2008;13(2):105-12.

6) Lins OG, Picton PE, Picton TW, Champagne SC, Durieux-Smith A. Auditory steady-state responses to tones amplitude-modulated at 80-110 Hz. J Acoust Soc Am 1995;97(5 Pt 1):3051-63.

7) John MS, Picton TW. MASTER: a Windows program for recording multiple auditory steady-state responses. Comput Methods Programs Biomed 2000;61(2):125-50.

8) Roberson JB Jr, O’Rourke C, Stidham KR. Auditory steady-state response testing in children: evaluation of a new technology. Otolaryngol Head Neck Surg 2003;129(1):107-13.

9) Lee A, Jiang D, McLaren S, Nunn T, Demler JM, Tysome JR, et al. Electric acoustic stimulation of the auditory system: experience and results of ten patients using MED-EL's M and FlexEAS electrodes. Clin Otolaryngol 2010;35(3):190-7.

10) Sininger YS, Abdala $C$. Hearing threshold as measured by auditory brain stem response in human neonates. Ear Hear 1996;17(5):395401.

11) Sininger YS. Auditory brain stem response for objective measures of hearing. Ear Hear 1993;14(1):23-30.

12) Gorga MP, Johnson TA, Kaminski JR, Beauchaine KL, Garner CA, Neely ST. Using a combination of click- and tone burst-evoked auditory brain stem response measurements to estimate pure-tone thresholds. Ear Hear 2006;27(1):60-74.

13) Park SK, Kim BJ, Hur DG, Lee KJ, Lee JH, Oh SH, et al. The Validity of auditory steady-state response as frequency-specific threshold test in infant-toddlers. Korean J Audiol 2006;10(2):105-11.

14) Johnson TA, Brown CJ. Threshold prediction using the auditory steady-state response and the tone burst auditory brain stem response: a within-subject comparison. Ear Hear 2005;26(6):559-76.

15) Kim LS, Jeong SW. Hearing threshold prediction using auditory brainstem response and auditory steady-state response in infants and young children. Korean J Otorhinolaryngol-Head Neck Surg 2011;54(9):592-602.

16) Swanepoel D, Ebrahim S. Auditory steady-state response and auditory brainstem response thresholds in children. Eur Arch Otorhinolaryngol 2009;266(2):213-9.

17) Miyagawa M, Nishio SY, Ikeda T, Fukushima K, Usami S. Massively parallel DNA sequencing successfully identifies new causative mutations in deafness genes in patients with cochlear implantation and EAS. PLoS One 2013;8(10):e75793. 